THE FLETCHER JONES FOUNDATION

HUMANITIESIMPRINH

The Fletcher Jones Foundation has endowed this imprint to foster innovative and enduring scholarship in the humanities. 
The publisher gratefully acknowledges the generous support of the Fletcher fones

Foundation Humanities Endowment Fund of the University of California Press Foundation. 
Walt Whitman and the Civil War 



\section{Walt Whitman and the Civil War}

America's Poet during the Lost Years
of I $860-1862$

Ted Genoways

\section{प}

UNIVERSITY OF CALIFORNIA PRESS

$$
\text { Berkeley Los Angeles London }
$$


University of California Press, one of the most distinguished university presses in the United States, enriches lives around the world by advancing scholarship in the humanities, social sciences, and natural sciences. Its activities are supported by the UC Press Foundation and by philanthropic contributions from individuals and institutions. For more information, visit www.ucpress.edu.

University of California Press

Berkeley and Los Angeles, California

University of California Press, Ltd.

London, England

(C) 2009 by The Regents of the University of California

\section{Library of Congress Cataloging-in-Publication Data}

Genoways, Ted.

Walt Whitman and the Civil War : America's poet during the lost years of $1860-1862 /$ Ted Genoways.

p. $\mathrm{cm}$.

Includes bibliographical references and index.

ISBN 978-0-520-25906-5 (cloth : alk. paper)

I. Whitman, Walt, I819-1892-Political and social views.

2. Whitman, Walt, I819-1892-Knowledge-United States.

3. Poets, American-19th century-Biography. I. Title.

$\mathrm{PS}_{3232 . G_{46}} 2009$

$8 \mathrm{I} \mathrm{I}^{\prime} \cdot 3$ - dc2 2

[B]

2009003369

Manufactured in the United States of America
$\begin{array}{llllllllll}18 & 17 & 16 & 15 & 14 & 13 & 12 & 11 & 10 & 09\end{array}$

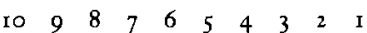

This book is printed on Natures Book, which contains $30 \%$ post-consumer waste and meets the minimum requirements of ANSI/NIso z39.48-I992 (R I 997) (Permanence of Paper). 